\title{
Pastoral Strategy in Developing the Dimension of Understanding Generation Z
}

\author{
Joni Manumpak Parulian Gultom, ${ }^{1 *}$ Fransiskus Irwan Widjaja, ${ }^{2}$ Martina Novalina, ${ }^{3}$ \\ Ester Lina Situmorang, ${ }^{4}$ Yohana Natassha ${ }^{5}$ \\ 1,2,4, 5 Sekolah Tinggi Teologi REAL, Batam, Indonesia \\ ${ }^{3}$ Sekolah Tinggi Teologi Ekumene, Jakarta, Indonesia \\ *email: jonimanumpakgultom@gmail.com
}

\begin{abstract}
The research center numbers released the results of the 2021 survey, where generation $\mathrm{Z}$ has the smallest spiritual index of 3.50, while the spiritual index of Indonesia is 3.79 . The index of understanding dimensions is low, namely 3.13 for self-image and 3.40 for motivation. This paper aims to find a new pastoral strategy in reaching generation $\mathrm{Z}$ for self-image restoration and motor development. The next goal is to build synergy with parents in spiritual growth. This study uses a qualitative method with data collection through literature study and observation. The argument is that shepherds play an essential role in developing the understanding dimension of Generation $Z$. The first step is to restore self-image with the Family Healing Movement with parents. The second thing is that pastors provide spiritual assistance to develop motivation and improve pastoral services on social media through counseling and training guidance. Her contribution; 1) pastors work together with parents to become inspirations and mediators in recovery, 2) spiritual practitioners take a fundamental part in social media, 3) maximize the pioneering of shepherding young people by new shepherds.
\end{abstract}

Key Words: pastoring; generation Z; self-image; motivation; social media.

Article History:

Submitted: Nov. 11, 2021

Revised: Jan. 11, 2022 (c) (1) (2)
Published: Jan. 29, 2022

This is an open access article under the CC BY-SA license

\section{INTRODUCTION}

The world has moved from the era of industry 4.0 to the period of society 5.0 , which makes $a$ hybrid life where public life is no longer face-to-face but active with the Internet of Things. All become needs and unity in daily life both in education, fashion, culinary, finance, and even spiritual matters (Purnomo \& Sanjaya, 2020). In the BRC's 2018 study, it was clear that 4,095 people aged $15-25$, the majority of generation $\mathrm{Z}$, were three items of concern for the pastoral team to change their ministry seriously. The first $21.2 \%$ said the church leadership team was terrible. The second thing $12.4 \%$ stated an unattractive form of ministry, and the third was that $12.4 \%$ said the church was filled with pretense. Up to $61.8 \%$ of this generation considers the church unattractive (Irawan \& Putra, 2018). The conclusion is that the pastoral team does not have a big vision, does not involve millennials in the responsibility of great ministry, and does not understand mindset and character. The first decision and action are that the pastoral team must provide a sense of comfort in worship to this generation. It is contemporary worship and the theme of preaching to the millennial generation.

Generation Z continues of generation $\mathrm{Y}$ with birth between 1995 and 2010. The total number of generations is the largest of all ages. It is also happening in the demographics of membership in the church (Subowo, 2021). Although this generation is very familiar with technological advances and social media, it does not move straight with their spiritual development. The conclusion of the 2021 Number Research Center study mentioned that generation $\mathrm{Y}$ and $\mathrm{Z}$ are the main targets of church services for coaching and discipleship 
related to their constrained spiritual needs. However, specifically, generation $\mathrm{Z}$, when considered more carefully, is more dominant to be addressed immediately. It can be seen from the spiritual index of generation $\mathrm{Z}$ is 3.50 (Indonesian spiritual index 3.79), with the lowest comparison value located in the dimension of, namely on the self-image variable (index 3.13) and motivation variable (index 3.40). These two variables are also very influential to the low index in the personal practice of spirituality (3.01) and evangelism - discipleship (2.63).

In quantity, their number is enormous, about 74.93 million or equivalent to $27.94 \%$ of the total population of Indonesia. When associated with the development of this generation for about seven years, they will reach a productive age that will dominate, become representatives and creators for the future (Jayani, 2021). Since childhood, this generation has been inseparable from digital devices, tablets, and smartphones with all its applications. Together with Generation $\mathrm{Y}$ is often referred to as Digital Generation, which is the generation that has been accompanied, studied, and interacted with digital devices, Digital Natives or 'Digital Natives' as the generation of owners of the XXI Century (Hidayat, Saefuddin, \& Sumartono, 2017). Connected generation in almost all elements, space and moving dynamic or mobile. They are in a life between the virtual world and reality. Digital Natives have a strong motivation in the two areas of life (Christiani \& Ikasari, 2020). The characteristics of generation $\mathrm{Z}$ are in addition to being proficient with technology and information, growing amid the rapid advancement of the digital world, using the internet massively so that it is insightful. The second characteristic is communicating with everyone, especially with social media. The third is that it is easy to boast privacy, so there is a widening gulf between wisdom and information. They cannot screen in the values and principles presented. Tend to be more independent by often making decisions without advice from family and others. The other thing is to be more tolerant of differences and ambitious to get what you want (Oktavia, 2021).
They are very adaptable, do not like authoritarianism, and use generation $\mathrm{Y}$ as a bridge to communicate with generation X (Christiani \& Ikasari, 2020).

Rumondang and Resmi, in their research, discussed the profound implications of pastoral teams taking part in the use of social media as a teaching medium for generation $\mathrm{Z}$ to build spirituality in the digital era (Gaol \& Hutasoit, 2021). Mr. Apaut and Suparman (2021) emphasizes spiritual change with an emphasis on the discipline of reading God's words. The method used is Bible reading journals in collaboration with teachers and parents as a practical step in building the spiritual discipline of reading the Bible (Apaut \& Suparman, 2021). Rumbiak (2020) examined the theological approach of worship to church practitioners virtually to develop the spirituality of generation $\mathrm{Y}$ and $\mathrm{Z}$ in strong fundamental values about transcendent and immanent elements. Exciting research from Kristyowati (2021) focuses on spiritual service with creative worship design in the utilization of Artificial Intelligence or artificial intelligence (simulation of human intelligence machined) and solutions to the concept of personal branding to the digital generation. While Subowo (2021) himself emphasized the church's role in intensive and massive communication using cyberspace, although it is not always spiritually charged. In essence, the church builds strong relationships in a virtual space to guide the spirituality of the digital generation (Subowo, 2021). There has been no other research that discusses in detail and in-depth the involvement of the church pastoral team in the development of spirituality from the dimension of understanding of generation $Z$, especially regarding unstable selfimage and motivation.

Therefore, how is the church's grazing strategy developing the dimension of this generation $\mathrm{Z}$ self-image? What about recovering their motivation? As well as what kind of grazing service steps in the virtual world can be? This research supports the renewal of strategies in the involvement of the church pastoral team. It continues to build the dimension of understanding 
of generation Z. So that in the end, they will become strong people in faith, have the principle of life, and can survive and live life in the proper spiritual practice every day. This research bridges the steps and strategies of fully responsible grazing in preparing this digital generation for 7-10 years for churches, ministries, and communities with life's challenges and changing times. Suppose the restoration and development of this dimension of understanding do not reach the desired Biblical standards. In that case, it is open to the decline of faith, personal helplessness, and spiritual defects when dealing with chaotic and religious patterns of the world and social media technological progress. The church and pastoral team have an essential role in unlocking spiritual insight and providing a direction for faith's strength in anticipating the value of wrong values spreading in this younger generation.

This paper argues that grazing has a significant role in restoring self-image and developing the motivation of generation $Z$. The first strategy is the concept of the Generation $\mathrm{Z}$ Healing Movement that cooperates with their families in self-image recovery. The second thing is with spiritual assistance to develop faithful and proper motivation. Moreover, the last thing is to improve grazing services in the social media space through personal counseling and training guidance. The purpose is to explain the new strategy of the pastoral team in shaping the recovery of the self-image of generation $\mathrm{Z}$. The next thing is to formulate a shepherd's approach in the growth of generational motivation and describe the practical steps of grazing in the use of social media.

\section{METHOD}

This study uses a qualitative method with data collection through literature study and observation. The primary data sources came from the Bible and pastoring books and journals. Which is descriptively to discuss shepherding strategies in building this dimension of understanding of Generation Z. First of all, the author re-describes the duties and roles of a pastor that should be carried out by giving a particular emphasis in dealing with the times. Then, the research aims to build the growth dimension of the understanding of Generation Z, especially in motivation and self-image. So that in the end, we got a new strategy in more effective stewardship in shepherding Generation $\mathrm{Z}$ both in the physical space and on social media to be productive and consistent. In addition, the author also observes how the existence of social levels, the depth of religious experience of Generation $\mathrm{Z}$ in local churches, places of worship, and the surrounding environment, as well as social media. Researchers are included in the study group both within the ministry of the Indonesian Bethel Church MY HOME Tanjung Pinang and House Of Glory Batam, Riau Islands. In addition, he also observed Generation Z in lecture classes at STT REAL Batam. At the same time, the shepherding ministry observation data was obtained by witnessing local church services and asking questions to get direct information from the pastors. Observations were also made by asking parents to accept data about this generation's relationship. The collection of observational data follows social science research which sees data naturally in human life without the need for specific categories and pre-estimated responses, intending to obtain new theories or hypotheses (Hasanah, 2016). Afandi relates spiritual values in the church that are face-to-face but are taught to the congregation in virtual media with good spiritual qualities (Afandi, 2018).

\section{RESULTS AND DISCUSSIONS}

This picture comes from measurable actions: reconstructing the local church's existing pastoral team membership structure. Pastoral teams are collaborations of leaders who imitate Christ. The character of church leaders has good character, is servant and compassionate, and can be trusted, not motivated to boast and seek personal gain (Tarigan, Hermanto, \& Olyvia, 2021). Therefore the central shepherds appointed more new leaders from generation $\mathrm{Y}$ and reduced the share of generation $\mathrm{X}$ 
and even baby boomers in the existing structure. In addition, the bridge of communication between generations minimizes the gap between the current differences leaders of the two generations above. However, the team continues to build the ministry by practicing the Christ leadership model that sees holistically the needs of the local congregation, primarily spiritual and personal development. In addition, the central Pastor becomes the primary mentor for the ministry of this young generation for the next generation and is willing to commit to having a particular time for this generation. The pastors have often delegated responsibilities to others due to busy schedules. It takes humility and a high spiritual burden to focus on service to this generation-form leadership classes and mentoring classes on an ongoing basis, specifically and expressly for them. Sagala (2020) states that pastors must have the ability to teach and disciple all church members. Meetings are with worship and other face-to-face meetings and virtual media, their lifestyle. Subowo (2021) paper shows that digital space can be used in worship meetings as a sacred space with religious values, although not face-toface. It in itself does not contradict God's Word because everything is from God to God and God and all for the glory of God (Romans 10:13-18). While the Bible itself never tells how Jesus healed two sick people without seeing them. It proves how the power of Christ and the Holy Spirit can work optimally even in a digital space (Luke 7:1-10; Mat. 15:21-28).

The principle of the ministry of the church pastoral team is that it should not be from the stage to the congregation but from Heaven to generations together glorifying God through the media of the church and its stewardship (Matthew 16:18-19; Acts 1:8;2:1-11). Church ministry should not forget spiritual warfare and the quality of commitment to loyalty. Spiritual life is focused on Sundays for 2 hours and experiencing God's presence as being satisfied. However, shepherding prepares them consistently and continuously to endure and maintain their faith when faced with any complicated situation. The church must be understood as a unity of an institution, spiritual communion, sacraments, preaching the gospel, and most importantly, the church as a servant of the congregation in the power of the Holy Spirit (Acts $1: 8)$. The pastoral team creates lively worship and can bring the community to enjoy God's presence. The Pastor trained new leaders and ministers and sent out as many as possible. The pastoral approach looks like a person who is God's representative in the church must impart spiritual values in building relationships with this generation (1 Peter 5:2-4; Ephesians 4:11-5).

Some approaches are 1) Be friends (James 2:23). The friendship between shepherds and the younger generation can be built with values of commitment to support each other, sacrifice each other to strengthen and cooperate, and have solidarity, which, despite the age difference, does not hinder communication and relationships (Manurung, 2021). The character of sincere humility and openness is the key to opening this generation. Do not be a hypocrite and look superior to them. Create a dedicated group with mentoring and leadership targets for more fluid communication; 2) Build a flexible ministry structure (2 Corinthians 6:3-10). A clear vision and mission must show with good management. Shepherd is concerned with writing, preaching, and explaining the vision and mission that God has given to this generation in all existing ministry methods. But that does not mean the church lets them work and move without supervision (Tong, 2019). The main point is the Pastor's evaluation and monitoring of the church's vision and mission for generations. Use social media as an integral part in realizing the Vivid mission for this generation to be saved and fulfill the Great Commission of Christ (Camerling, Lauled, \& Eunike, 2020). It starts with the local church, service, sermons Sunday or other days, and prayer meetings and cell communities. They describe this method of vision and mission in small groups. That is where the Pastor conducts the learning and training classes. The results of the research, targets, 
and longing for this generation can be heard again and repeated in church services, both in word, testimony, or prayer (Dunaetz, 2021); 3) Anointing and sending (Matthew 16:18-19, Acts 1:8). Shepherd leadership prepares and empowers the younger generation on a mission to serve the needs of souls in the digital era (Munthe, 2019). There is a tendency for great and entitled people to be experienced and more mature. It is not a definite measure. The reason is that the Bible itself guarantees that young people can function for His glory. The Pastor plans to anoint and send the pastoral team, God's congregation, and their parents at a specific time. The Holy Communion moment at the beginning of the month becomes an excellent momentum to show the value and importance of the vision and mission. The significance of Jesus' sacrifice reminds us of the preciousness of fellowship with Christ always to enjoy God's assurance of the Eternal Kingdom. Holy Communion gives hope and opens divine fellowship among believers into one body, one purpose, and one God (Sumiyati \& Mendrofa, 2021).

Through its pastoral team creating new leaders and ministers, the church provides opportunities and opens the stage of ministry for this generation as wide as possible. It relates to changes in the mindset of contemporary ministries, which generally rely entirely on building physical churches or tents for services using social media in the digital era. These are high collaborations utilized in joint ministry that can increase active interpretation to serve, fellowship, and testify (Darmawan, Giawa, Katarina, \& Budiman, 2021). So that this generation gets the opportunity to learn to self-actualize, be burdened with serving God better, and be able to take responsibility for the tasks that are the burden of God's call in his life, especially and especially.

\section{Family Healing Movement as a Means of Self- Image Recovery}

This generation is very open to the outside world but cannot winnow incoming information
(Subowo, 2021). They are very independent and responsive in socializing with the community in the media world. In addition to classic problems in everyday life, virtual space has made them have idol figures from among artists, actors, sports figures, music. Do not even miss influencers such as Selegram and YouTubers, most of whom do not know biblical life principles (F. Simanjuntak, Sidabutar, \& Sanjaya, 2020). Since childhood and for a relatively long period, this generation has lived with wrong values that affect their self-image in seeing faith, hope, and authentic truth. Indeed, they care deeply about health, an age that values choice, freedom, flexibility, and personal control, says Tom Capone, Research Assistant for Health Policy Studies at the Cato Institute (Given, Hannaford, \& Zaiac, 2015). White explained that the characteristics of Generation $\mathrm{Z}$ are that they are very independent. They look at the dystopia of the future and worry about the present. It makes them want to work quickly and earn money with a tendency to work independently. Second, They are active with wifi or internet generation. They spend time and obtain information from digital media. The third thing is the massive gap between wisdom and acquired knowledge. With the power of social media being so fluid, they try to please as many people as possible with their posts by minimizing conflict and tension.

Moreover, the fourth characteristic of concern is that this generation lives without gender differences and deep relationships. Religious circles do not care that gays and lesbians are a sin and a curse. Absolute personal freedom has been instilled since childhood (White, 2017). They lose their normal childhood because of the penetration of technological advances, giving them a tendency to grow up faster. Due to very active gadgets, it exposed to pornography and hoax info. However, this generation is more brilliant and can do many things in one situation (multi-tasking) than the previous generation.

The real challenge for restoring this generation's self-image tends to come from the 
parents because the growth of Christianity between ages is hampered (Tafona'o, 2016). However, teachers as educators have the main task in theological studies of education that can describe faith with integrated knowledge and develop new concepts to build generations (J. M. Simanjuntak, 2018). However, the self-image of the age can also experience maximum recovery if the person experiences a divine encounter personally with God in the method of forgiveness and personal selfacceptance and returns to the Imago Dei at the beginning of creation (Padang, Manumpak, \& Gultom, 2018). From some of these studies, Some approaches can restore the self-image of generations. However, the author sees the family side as the starting point for a practical self-image recovery approach. One of the reasons is that Paul uses the Family as a mission center outreach to the most basic community (Lahagu, 2020).

Meanwhile, Lie (2019) saw that the Divine Covenant between generations was obtained based on spiritual education in the Family based on the study of theology and the history of Covenant theology. Meanwhile, Santoso (2019) ranks Family as the second priority element after God Himself. The Family is the central part of the soul group that must shepherd to the maximum. Therefore, it is clear that the restoration of the self-image of Generation $\mathrm{Z}$ is determined mainly by the level and quality of faith and divine character in their own Family. The local shepherd must see the side of life and the relationship between these two subjects for healing action.

Howe and Struss, who wrote the millennial generation, developed into an age of power generators, technology designers, the wider community, and even the success of the last 100 years or so from their predecessors. They are active, loyal followers, pay close attention to their predecessors. The others they innovative generations and stand the test. Still, this development is terrifying because the traditional and manual means cannot control it, like positive development and negative impacts (Howe \& Strauss, 2000). Different steps are needed to restore and develop a proper self-image to them. The pastoral team must work together with other parties to see a picture of themselves that must improve. Following Tidball's (2021) statement, pastors are humble and eliminate the gap in the service stage. They must have skills in seeing the side of current needs, be skilled in presenting the truth of God's word contextual, and lead the flock served and prepare themselves for ministry work.

The concept that can be a solution is the family Healing Movement method, where the church pastor becomes the mediator in bringing the family together as a whole. This effective selfimage restoration of Generation $\mathrm{Z}$ starts from the family itself. The unity of the heart and the value of the correct self-image in the family have begun to disappear. The church pastor becomes a divine mediator to bring parents and their children to a personal encounter with God again. Many cases occur in families that the advancement of media technology and their respective activities unconsciously create a gap in the relationship between parents and children. There is no continuous quality time, with deep and warm verbal communication about everyday life. In this opportunity, they learn to be open, honest, and united by forgiving and accepting each other's existence. Whole families remain in God's safety and love, able to face the destructive values of globalization and social media. It is crucial to consider that IT factors caused the gap between children and parents, the development of the times, and the community. The Pastor can do the retreat concept in a particular location or place to focus and maximize. The Pastoral Team prepares words and values about the accurate self-image of God the Father in Jesus Christ for parents and children. Create small family groups and allow time for evaluation and openness.

The pastoral team must be a moderator who can break the deadlock. Therefore, the Divine Family Healing Movement must start from the family of the Servant of God and the pastoral team, 
and the core ministers of the local church because the family of God's servants and shepherds are the core of the movement and restoration of generations (Santo \& Simanjuntak, 2019). It is continuous and can repeat as needed with an adjusted number of participants. The pastoral team must maximize duties and gifts for forming the self-image of generation Z. Munthe (2019) states the pastoral ministry speaks the revealed gift of the Holy Spirit. The Holy Spirit can change the self-image of this generation $\mathrm{Z}$ in the divine encounter. Sometimes the church and the pastoral team have to invest money because not all families have sufficient finances.

\section{Spiritual Mentoring as a Method of Motivation Development}

In addition, the church and the pastoral team must provide spiritual assistance in the local church with regular and intentional intensive face-to-face meetings, both formal and informal. They are close to $70 \%$ of the general church membership. The single most important thing to do is to educate this generation. They have no burden to be in missions and evangelism. Shepherds must maximize their optimal responsibilities in reaching them (Gultom, Bunthu, Tomasoa, \& Nduru, 2019). The point is to keep getting involved and give them a moment of togetherness. Give trust and support, not insults, when there is a small or fatal mistake-open space in accepting the shortcomings and helplessness mentally but with a great sense of forgiveness. Proverbs 22:6 mentions teaching young people according to the right way for them. Mr. Pailang and Palar's paper states that discipleship spirituality requires adults who have spiritual capacities, such as church ministers and parents. They can influence and contribute to their spiritual development through the practice of the word to become a blessing (Pailang \& Palar, 2012). Meanwhile, one effective method of revealing the truth of God's word to enlighten and strengthen children's faith is reading, contemplating, and acting carefully (Nainupu \& Emiyati, 2020).
The church pastoral team becomes spiritual educators in local ministries. They must act as spiritual parents who give them the freedom to provide them with spiritual space to express their knowledge of God according to their growth stage. Let them show their worth, a community without distance, socialization, and creative ideas that become strengths. Paul stated that he was your father because of the gospel preached with commitment and faithfulness even with thousands of educators around them (1 Corinthians 4:15). In Romans 4:17-18, Abraham mentioned the father of all nations concerning the great faith.

Often they face doubts and fears in starting anything new in terms of spiritual practice. They are very dependent on the virtual world in their daily lives, so they experience problems building relationships, communication, leadership, and physical authority (Gaol \& Hutasoit, 2021). Therein lies the openness of the pastoral team to give them a sense of responsibility for the actions they want to take. Borong stated that shepherd leadership is being able to humble oneself with the soul served (Borrong, 2019). Service and form a religious community with a pattern of building relationships and connectivity with each other's personalities. It is the approach to making this generation's motivation. The theory of motivation by O'Neil \& Drillings (2012) concerns the cognitive dimensions in the learning process or knowledge sharing, which includes the absorption and storage of meaning and scientific procedures. Motivation contains several components, such as effort, anxiety, and curiosity, in stages. Two factors determine personal reason: first, individual characteristics vary on two things, namely the treatment of individuals and separate statements (Kaplan \& Haenlein, 2010). Entrust them with the ministry and spiritual burdens they can reach. It is not only a pulpit service but also on a stage. The pastoral team conducts discipleship classes such as preaching, missions, and evangelism classes. Get them to be active and feel free to receive gifts from God. 


\section{Social Media and Virtual Shepherd Stewardship}

Pastoral strategies with face-to-face media alone are not perfect in building the growth dimension of this generation's understanding. Several strategies made in educational institutions, but the church has not responded much to them. The church must make a breakthrough to maximize the spiritual development of this generation as soon as possible. For example, the development of social media and information technology which experienced a high jump in the Covid-19 pandemic era has provided a new discourse in serving in various categories in improving service and quality of stewardship in the church's vocation as a whole in fellowship, community service, and testimony (Darmawan et al., 2021). The church and stewardship are transforming physical to virtual services increasingly massive and an excellent opportunity to reach the digital generation. Virtual space has become the next force to reach them.

They can do several concepts in the media. Several types of Social Media can be used as part of virtual ministries, such as Collaborative Projects, where churches and teams make worship and praise content and worship accessible to a global audience. The second thing is to create church Blogs and Microblogs (Rahadi, 2017). This generation can express everything such as news, opinions, experiences, or daily activities, whether in text, images, videos, or a combination of the three. Of course, there are biblical standards and Christian ethics that are upheld. However, It can maximize these two applications in conveying the church's vision, mission, and spiritual targets and activities. However, the local church pastoral team provided and pioneered Social Networking Sites among Generation $\mathrm{Z}$ as a medium for connecting with other members and forming a community. As Lewis described, they use social media in everyday life, even in the spiritual sphere. This space is filled with observations to explore ideas, self-regulation and normalize the values to be conveyed (Lewis, 2018).

\section{Social Media as a Consultation Room for Handling Youth Problems}

Pastoral counseling is an entry point for this generation to pour out the heart and the turmoil that occurs. This generation is used to the emoji language with symbols without a narrative to express their thoughts and feelings. This generation is fast-paced in anticipating changes, works faster and easier, and affiliating with internet applications. Meanwhile, in the context of religion, it will be easy to acculturate with virtual culture with a tendency to obscure doctrine and teaching (Kristyowati, 2021). Often family and friends become stiff and slow to share stories and solutions, but in the media world, they can overcome this. By looking at the data, almost $93 \%$ of millennial children use social media in communicating and doing activities. Therefore, it is necessary to regulate information so that it does not come from virtual sources but also verbal communication from the closest people (Ahmad, 2020). There are a lot of mental health and psychological counseling agencies in applications today. However, it is almost impossible to find a church with a counseling team for a virtual room. That is why we need a pastoral counseling team fully responsible for this ministry in the media. Its nature can be directly (live) or interactive with various available platforms. Bringing in young Christian influencers as moderators or supporters of the event to make live content better and more enjoyable is necessary.

They introduced program promotions and event endorsements both within the church and media. The most important thing is that the pastoral team can provide as much access as possible to Generation $\mathrm{Z}$ and participate freely without feeling afraid or pressured. It is the answer to the many hoax news they face. Rahadi states that hoax information is spreading in this generation and must be observed in the form of fake news, which is deliberately created to obscure the truth and facts. Click Bait, which is a link to trap people to enter hoax news links, confirmation bias, Misinformation, Satire, Post Truth to Propaganda, false information affects 
public opinion (Rahadi, 2017). When you see the many doors of misinformation and misleading information from social media to this generation, a unique virtual consultation room from the church is one solution to anticipate it. In line with the Zaluchu (2020) paper, although hoaxes, disinformation, and news are presented in the same direction, spiritual development always provides opportunities to grow in social media with continuous literacy and teaching.

\section{Extensive Tutoring and Virtual Training}

It is something new to be used as an alternative with the limitations of face-to-face generation. However, the advantages of this guidance and training can cover many people from various places. The key is a connection, relationship, and need. Generation $\mathrm{Z}$ is open to religious matters but is easy to be skeptical. It happens because the level of understanding is not rooted and fundamental? This generation is in contact with gadgets every day with the advantages of multi-tasking, very open, creative, innovative, critical, and collaborative.

Nevertheless, cynical, skeptical, and very dependent on technology, so they are constantly vigilant at all times (Kristyowati, 2021). The interest in worship and worship of $57 \%$ of those aged 18-29 years decreased drastically in the Barna Research survey. While the Research Center Numbers research always increases the rate of decline from generations aged 15-18 years to $19-22$ years and 23-25 years as much as 2-3\%. It illustrates that pastoralism for this generation with stewardship management adapted in the digital media world has not been able to reach them optimally (Gultom, 2021). Therefore, extensive guidance and training for pastors and their stewards must be carried out to produce effective and efficient penetration and service actions. Recognize changes, developments that occur and start upgrading yourself as soon as possible, either independently or with the help of experts in their fields.
Requires additional time and opportunities are needed packaged using the Google Classroom platform, Zoom, with a pastoral team that can turn it into a webinar. It does not have to be a local pastoral team that becomes a resource, but you can invite other speakers who are more familiar with virtual content. It maintains a connection with a personal person who is familiar with them. Haryono, in his paper, shows that these things can maximize Christian professionals to take part in the digital space. Multifunctional ability and experience in the world of work can be a new force to form creativity in services in the digital era (Haryono, 2021). The time required is, of course, adjusted to the subject being discussed. Take time to discuss with the trainees and discuss simple questions about certain things such as humanity, morals, ethics, and eternal life to be interested and enthusiastic to respond (Padang et al., 2018). According to Kristyowati (2021), the solution is where the church can build a generation $\mathrm{Z}$ personally and spiritually, namely by using AI Artificial Intelligence and Personal branding in building this generation to have better faith, mentality, and the ability to develop multiple intelligences. Pastors and their stewards must create and maximize their ministry in the social media space with an approach that is their passion and interest. Characters with high spiritual values are created and must be developed sustainably and in a media space.

\section{CONCLUSION}

With its massive number of members in the local church, Generation $\mathrm{Z}$ is experiencing significant spiritual obstacles and challenges. The spiritual index of understanding dimensions, namely self-image and motivation, is low. Therefore the pastoral team has a big responsibility to reach them with the first strategy through the Healing Movement, which works with their families in self-image restoration. The second, spiritual assistance to develop authentic and essential motivation. Moreover, the last thing is to increase pastoral care services through personal counseling 
and training guidance in the social media space. So that the local church and pastoral team can shape the spiritual growth of Generation Z. They teach them to the maximum with practical steps in restoring self-image and motivation to work with parents and maximum use of social media. Christlike humility is the key to effective shepherding. Allocate more significant church finances to classes, special

\section{REFERENCES}

Afandi, Y. (2018). Gereja Dan Pengaruh Teknologi Informasi "Digital Ecclesiology." FIDEI: Jurnal Teologi Sistematika Dan Praktika, 1(2), 270-283. https://doi.org/10.34081/fidei.v1i2.12

Ahmad, A. (2020). Media Sosial dan Tantangan Masa Depan Generasi Milenial. Avant Garde, 8(2), 134-148.

https://doi.org/https://doi.org/10.36080/ag.v8i2 .1158

Apaut, V. A., \& Suparman. (2021). Membangun Disiplin Rohani Siswa pada Generasi Z melalui Jurnal Membaca Alkitab. Diligentia: Journal of Theology and Christian Education, 3.

Borrong, R. P. (2019). Kepemimpinan Dalam Gereja Sebagai Pelayanan. Voice of Wesley: Jurnal Ilmiah Musik Dan Agama, 2(2). https://doi.org/10.36972/jvow.v2i2.29

Camerling, Y. F., Lauled, M. C., \& Eunike, S. C. (2020). Gereja Bermisi Melalui Media Digital Di Era Revolusi Industri 4.0. Visio Dei: Jurnal Teologi Kristen, 2(1), 1-22. https://doi.org/10.35909/visiodei.v2i1.68

Christiani, L. C., \& Ikasari, P. N. (2020). Generasi Z dan Pemeliharaan Relasi Antar Generasi dalam Perspektif Budaya Jawa. Jurnal Komunikasi Dan Kajian Media, 4(2), 84-105.

Darmawan, I. P. A., Giawa, N., Katarina, K., \& Budiman, S. (2021). COVID-19 Impact on Church Society Ministry. International Journal of Humanities and Innovation (IJHI), 4(3), 9398. https://doi.org/10.33750/ijhi.v4i3.122

Dunaetz, D. R. (2021). Barriers to Leading Small Groups among Generation $\mathrm{Z}$ and Younger Millennials: An Exploratory Factor Analysis gatherings in their personal and spiritual development. Furthermore, finally, the church and the pastoral team should never feel inferior and lose their authority to accompany them to become friends and mentors. Giving time, energy, finances, and shepherd also provides total confidence for them to be in a sustainable ministry space.

and Implications for Recruitment and Training. Christian Education Journal, 20(10), 1-18. https://doi.org/10.1177/07398913211018482

Gaol, R. L., \& Hutasoit, R. (2021). Media Sosial

Sebagai Ruang Sakral: Gereja yang Bertransformasi bagi Perkembangan Spiritualitas Generasi Z dalam Era Digital R. Kenosis, $\quad 7(1), \quad$ 146-172. https://doi.org/10.37196/kenosis.v1i1.284

Given, C., Hannaford, P., \& Zaiac, N. (2015). A Future for Millennials (C. Given, P. Hannaford, $\&$ N. Zaiac, Eds.). United States Of America: Young Voices.

Gultom, J. M. P. (2021). Penggembalaaan yang Efektif bagi Generasi Milenial di Era Society 5. 0. Shiftkey, 11(2), 95-108. https://doi.org/10.31219/osf.io/5puqj

Gultom, J. M. P., Bunthu, F. P., Tomasoa, F. P., \& Nduru, F. E. (2019). Generasi Millenial Dan Kaitan Tugas Yeremia Dalam Kegerakan Pantekosta. Real Didache, 4(1), 12-25.

Haryono, T. (2021). Pelayanan Multifungsi Profesional Kristen dalam konteks Era Revolusi. Gamaliel, 3(2), 72-84. https://doi.org/https://doi.org/10.38052/gamalie 1.v3i2.76

Hasanah, H. (2016). Teknik-teknik observasi. AtTaqaddum, 8(1), 21-46.

Hidayat, Z., Saefuddin, A., \& Sumartono, S. (2017).

Motivasi, Kebiasaan, dan Keamanan Penggunaan Internet. Jurnal ILMU KOMUNIKASI, $13(2), \quad 129$. https://doi.org/10.24002/jik.v13i2.675

Howe, N., \& Strauss, W. (2000). Millennials Rising, 
The Next Gret Genertion (First). United States Of America: Vintage Original.

Irawan, H., \& Putra, C. A. (2018). Gereja Sudah Tidak Menarik Bagi Kaum Muda, [The Church Is Not Attractive To Young People]. Retrieved from Bilangan Research Center website: http://bilanganresearch.com/gereja-sudahtidak-menarik-bagi-kaum-muda.html

Jayani, D. H. (2021). Proporsi Populasi Generasi Z dan Milenial Terbesar di Indonesia.

Kaplan, A. M., \& Haenlein, M. (2010). Users of the world, unite! The challenges and opportunities of Social Media. Business Horizons, 53(1), 5968.

https://doi.org/10.1016/j.bushor.2009.09.003

Kristyowati, Y. (2021). Generasi "Z” Dan Strategi Melayaninya. Ambassadors: Journal of Theology and Christian Education, 2(1), 23-34.

Lahagu, A. (2020). Keluarga Sebagai Pusat Misi Masa Kini. osf.io.

Lewis, B. (2018). Social media, peer surveillance, spiritual formation, and mission: Practising Christian faith in a surveilled public space. Surveillance and Society, 16(4), 517-532. https://doi.org/http://dx.doi.org/10.24908/ss.v1 $6 \mathrm{i} 4.7650$

Lie, T. G. (2019). Rancangan Praksis Pendidikan Kristen Berbasis Keluarga Beriman dari Generasi ke Generasi. Veritas: Jurnal Teologi Dan Pelayanan, 18(2), 125-140. https://doi.org/10.36421/veritas.v18i2.331

Manurung, K. (2021). Alkitab Dan Hubungan Pertemanan Kajian Teologi Pentakosta Memaknai Hubungan Pertemanan Dalam Alkitab. VOX DEI: Jurnal Teologi Dan Pastoral, 2(1), 31-49. https://doi.org/10.46408/vxd.v2i1.35

Munthe, E. (2019). Mengoptimalkan Karunia dalam Jemaat untuk Melakukan Misi Amanat Agung di Era 4.0. EPIGRAPHE: Jurnal Teologi Dan Pelayanan Kristiani, 3(2), 133. https://doi.org/10.33991/epigraphe.v3i2.127

Nainupu, A. M. Y., \& Emiyati, A. (2020). Kunci Keberhasilan Seorang Anak Dalam Pemaparan
Alkitab. Didache: Journal of Christian Education, l(2),

91.

https://doi.org/10.46445/djce.v1i2.329

O’Neil, H. F., \& Drillings, M. (2012). Motivation:

Theory and Research. (Second; M. D. Harold F. O’Neil, Ed.). New York: Taylor \& Francis.

Oktavia, W. (2021). Memahami 6 Karakter Generasi Z, Bukan Cuma Familiar Teknologi Sejak Kecil.

Padang, D. R., Manumpak, J., \& Gultom, P. (2018). Implementasi Kognitif Therapy Dalam Menghilangkan Rasa Minder Pada Mahasiswa STT REAL Batam Kelas Reguler Berdasarkan 1 Timotius 4 : 12. Real Didache: Jurnal Teologi Dan Pendidikan Agama Kristen, 3(2), 42-49.

Pailang, H. S., \& Palar, I. P. (2012). Membangun Spiritual Remaja Masa Kini Berdasarkan Amsal 22 : 6. Jurnal Jaffray, 10(1), 59-86.

Purnomo, A., \& Sanjaya, Y. (2020). Tantangan dan Strategi Gereja Menjalankan Misi Allah dalam Menghadapi Penerapan Industri 4.0 di Indonesia. DIEGESIS: Jurnal Teologi Kharismatika, 3(2), 91-106.

Rahadi, D. R. (2017). Perilaku Pengguna Dan Informasi Hoax Di Media Sosial. Jurnal Manajemen Dan Kewirausahaan, 5(1), 58-70. https://doi.org/10.26905/jmdk.v5i1.1342

Rumbiak, A. K. (2020). Teologi Ibadah dan Spiritualitas Generasi Milenial. Amreta, 3(2), 64-100.

Sagala, L. D. J. F. (2020). Tugas Pedagogis Gembala Dalam Menyiapkan Warga Gereja Menghadapi Perubahan Sosial. Evangelikal: Jurnal Teologi Injili Dan Pembinaan Warga Jemaat, 4(2), 167-174. https://doi.org/10.46445/ejti.v4i2.253

Santo, J. C., \& Simanjuntak, D. T. (2019). Pengaruh Keteladanan Hidup Gembala Sidang terhadap Pertumbuhan Gereja. KHARISMATA: Jurnal Teologi Pantekosta, 2(1), 28-41. https://doi.org/10.47167/kharis.v2i1.23

Santoso, J. (2019). Pelayanan Hamba Tuhan dalam Tugas Penggembalaan Jemaat, [Servant of God's Servant in Shepherding the Congregation]. Santum Domine, 9(1), 1-26. 
https://doi.org/https://doi.org/10.46495/sdjt.v9i 1.55

Simanjuntak, F., Sidabutar, D. L., \& Sanjaya, Y. (2020). Amanat Penggembalaan dalam Ruang Virtual, [Pastoral Commissions in Virtual Space]. Thronos, 1(2), 99-114.

Simanjuntak, J. M. (2018). Belajar Sebagai Identitas Dan Tugas Gereja. Jurnal Jaffray, 16(1), 1-24. https://doi.org/10.25278/jj71.v16i1.279

Subowo, A. T. (2021). Membangun Spiritualitas Digital bagi Generasi Z, [Building Digital Spirituality for Generation Z]. Dunamis, 5(2), 379-395.

https://doi.org/https://doi.org/10.30648/dun.v5i 2.464

Sumiyati, S., \& Mendrofa, E. (2021). Implikasi Pedagogis Pada Sakramen Perjamuan Kudus Dalam Liturgi Gereja. Evangelikal: Jurnal Teologi Injili Dan Pembinaan Warga Jemaat, 5(1), 116. https://doi.org/10.46445/ejti.v5i1.314 Tafona'o, T. (2016). Pendidikan Agama Dalam Masyarakat Majemuk. In Fondasia (2nd ed., Vol. 1). Jakarta: illumiNation Publishing. https://doi.org/10.21831/foundasia.v1i9.5868 Tarigan, S., Hermanto, Y. P., \& Olyvia, N. (2021). Kepemimpinan Tuhan Yesus di Masa Krisis Sebagai Model Kepemimpinan Kristen Saat Ini. Teologi Dan Kepemimpinan Kristen, 6(1), 3854.

Tidball, D. J. (2021). Teologi Penggembalaan (Keenam). Malang: Gandum Mas.

Tong, J. (2019). Theories of Leadership and Church Management. Excelsis Deo: Jurnal Teologi, Misiologi, Dan Pendidikan, 3(1), 1-16. https://doi.org/10.51730/ed.v3i1.6

White, J. E. (2017). Meet Generation Z: Understanding and Reaching the New PostChristian World (1st ed.; J. E. White, Ed.). United States Of America: Baker Publishing Group.

Zaluchu, S. E. (2020). Dinamika Hoax, Post-Truth dan Response Reader Criticism di Dalam Rekonstruksi Kehidupan Beragama. Religió: Jurnal Studi Agama-Agama, 10(1), 98-117. https://doi.org/10.15642/religio.v10i1.1310 